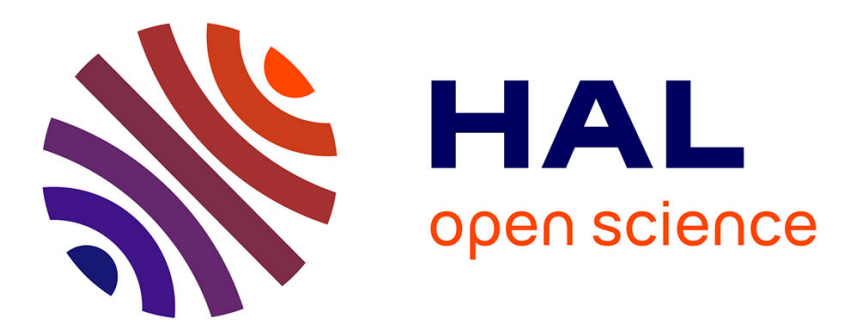

\title{
ANALYSIS OF FAILURE IN WOVEN CARBON/EPOXY LAMINATES UNDER QUASI-STATIC AND IMPACT LOADING
}

J. Harding, Y. Li

\section{- To cite this version:}

J. Harding, Y. Li. ANALYSIS OF FAILURE IN WOVEN CARBON/EPOXY LAMINATES UNDER QUASI-STATIC AND IMPACT LOADING. Journal de Physique IV Proceedings, 1991, 01 (C3), pp.C3-51-C3-59. 10.1051/jp4:1991307 . jpa-00249898

\section{HAL Id: jpa-00249898 https://hal.science/jpa-00249898}

Submitted on 1 Jan 1991

HAL is a multi-disciplinary open access archive for the deposit and dissemination of scientific research documents, whether they are published or not. The documents may come from teaching and research institutions in France or abroad, or from public or private research centers.
L'archive ouverte pluridisciplinaire HAL, est destinée au dépôt et à la diffusion de documents scientifiques de niveau recherche, publiés ou non, émanant des établissements d'enseignement et de recherche français ou étrangers, des laboratoires publics ou privés. 
Colloque C3, suppl. au Journal de Physique III, Vol. 1, octobre 1991

\title{
ANALYSIS OF FAILURE IN WOVEN CARBON/EPOXY LAMINATES UNDER QUASI-STATIC AND IMPACT LOADING
}

J. HARDING and Y,L. LII (1)

Department of Engineering Science, University of Oxford, Parks Road, GB-Oxford OX1 3PJ, Great-Britain

Résumé: Une méthode par élément finis est utilisée pour déterminer le facteur de concentration de contraintes en traction et les contraintes de cisaillement interlaminaire proches du pli fissuré dans un stratifié imprégné, en époxy renforcé au carbone, sous contraintes de traction. La fissuration du pli est modélisée par une diminution de la rigidité dans la direction du chargement. Différentes diminutions de la rigidité, représentant la rupture soit de la matrice, soit de la fibre, sont étudiées et on détermine le système de la redistribution de la contrainte dans le cas où la délamination suit la fissure du pli initial. Les résultats de l'analyse théorique sont discutés à la lumière des données expérimentales des tests en traction sur un stratifié similaire avec chargement quasi-statique et par impact.

\begin{abstract}
A finite element method is used to determine the tensile stress concentration factors and the interlaminar shear stresses close to a failed ply in a woven carbon reinforced epoxy laminate under tensile loading. Ply failure is modelled by a reduction in stiffness in the loading direction. Different reductions in stiffness, representing either matrix break-up or fibre tow fracture are studied and the redistributed stress system, for the case where delamination follows initial ply failure, is also determined. The results of the theoretical analyses are discussed in the light of experimental data from tensile tests on a similar laminate at both a quasi-static and an impact rate of loading.
\end{abstract}

\section{Introduction}

A recent attempt [1] to use laminate theory and a Tsai-Wu type failure criterion to predict the failure strength of woven carbon/glass hybrid laminates at both quasi-static and impact rates of loading achieved only limited success, partly because the laminate theory approach ignores outof-plane stresses, which will vary with the stacking sequence, but also because it was assumed that the carbon reinforced plies, in which first failure always initiates, all failed at the same critical level of applied stress. In practice, experimental results show that the critical fracture stress, both for single carbon fibres and for carbon fibre tows, follows a statistical distribution [2] so that not all fibre tows

(1) On leave from the Northwestern Polytechnical University, $X i$ 'an, People's Republic of China. 
will fracture simultaneously. Although this statistical variation is expected to be much less significant for a woven, rather than a unidirectional, reinforcement and for the resin break-up process rather than for fibre fracture, the assumption of a single critical load at which all the carbon-reinforced plies will "fail" is likely to be a gross over simplification. In reality the failure process in any given wovenreinforced ply almost certainly involves both a break-up of the resin matrix and the fracture of individual fibres or fibre tows followed by some combination of fibre pull-out and delamination. Since a laminate theory approach cannot be expected to take account of all these various processes the limited success achieved when it is used to predict hybrid tensile strength is not surprising.

It is possible, however, using the finite element method, to make at least some qualitative progress towards distinguishing between those processes which depend on the magnitude of the tensile stress, e.g. fibre or fibre tow fracture, and those which depend on the magnitude of the shear stress, e.g. delamination and fibre pull-out: The present paper describes an attempt to do this for a non-hybrid plain weave carbonreinforced laminate. Initiation of failure is modelled by a local reduction in the tensile stiffness for a given ply. Different reductions in stiffness are used, a smaller reduction to represent failure by the break-up of the resin matrix, a larger reduction to represent fracture of the given carbon reinforced ply. In each case the tensile and shear stress distributions close to the failed region are estimated. The relative values of tensile stress concentration, in the adjacent plies, to interlaminar shear stress, at the interface between the failed ply and its nearest neighbours, will give a qualitative indication as to the next stage in the failure process. The analysis is limited to a specific lay-up of woven carbon/epoxy laminate for which experimental data are available $[3,4]$. The finite element method used here closely follows that described in a recent paper on the failure analysis of woven hybrid composites [5].

\section{Finite Element Analysis Technique}

The ply lay-up in the central parallel region of the test specimen used in the earlier experimental work $[3,4]$ is shown schematically in Fig. 1 . It consists of 6 reinforcing plies each containing 5 carbon fibre tows

TABLE I

Elastic Constants for Carbon Reinforced Plies

$\begin{array}{lllll}\mathrm{E}_{1} & \mathrm{E}_{2} & v_{12} & v_{21} & v_{21} * \\ (\mathrm{GPa}) & (\mathrm{GPa}) & & \end{array}$




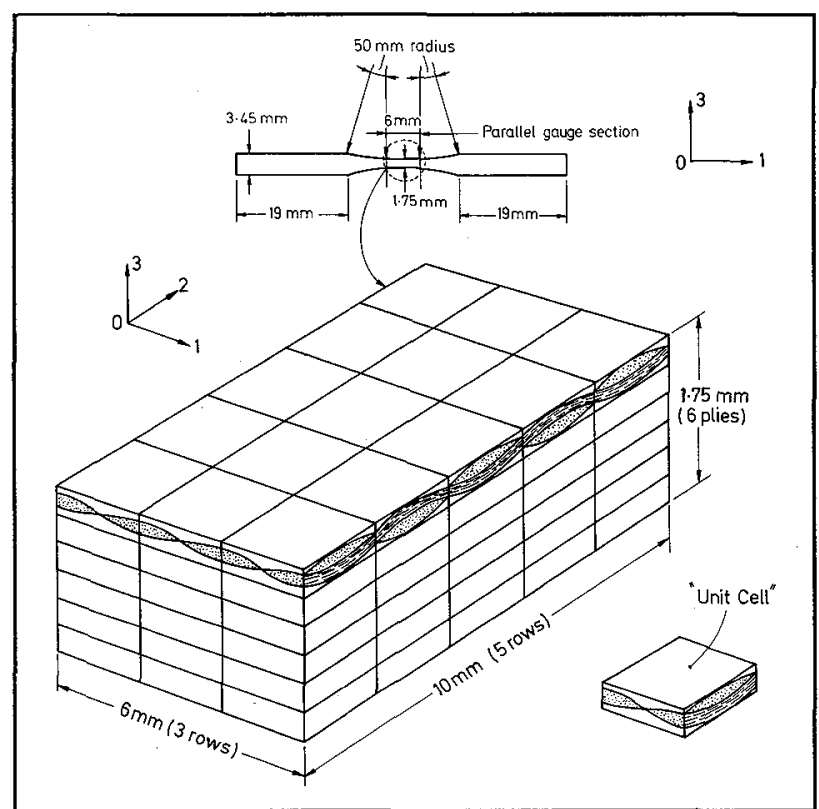

Fig. 1 Idealised Model of Ply Lay-Up in Central Parallel Region of Composite Tensile Test specimen aligned with the tensile axis, i.e. in the 01 direction. Each reinforcing ply may be divided into 15 nominally identical repeating units, or "unit cells", which are treated as if they were homogeneous and orthotropic with the elastic properties given in Table I. The in-plane elastic constants were determined experimentally in tension tests at a quasi-static rate of strain [4]. Also listed is Poisson's ratio, $v_{21} *$, determined using the symmetry hypothesis for an orthotropic laminate, i.e. $E_{1} v_{21}=E_{2} v_{12} *$. The finite element analysis also requires a knowledge of the elastic properties in the throughthickness direction, direction 03. In the absence of any experimental data on the elastic properties in this direction an estimated value for $\mathrm{E}_{3}$ of $6.0 \mathrm{GPa}$, based on the rule of mixtures and a fibre volume fraction of $50 \%$, was assumed and the corresponding Poisson's ratio, $v_{13}$, was taken to be 0.15 .

The analysis assumes a state of plane strain. A mesh consisting of 180 elements, each $0.2 \mathrm{~mm}$ long, see Fig. 2, was used, there being 10 such elements along the length of each unit cell. Initial tensile failure is assumed to occur in one of the elements adjacent to the central crosssection of the specimen and is modelled by a reduction in the longitudinal modulus, $E_{1}$, by a factor of $0.1,0.01$ or 0.001 . This is followed either by a further tensile failure in a neighbouring ply, controlled by the local tensile stress concentration, or by a delamination between the failed ply and its immediate neighbours, controlled by the local shear stresses. Which of these mechanisms operates will depend on the redistributed stress system in the vicinity of first failure.

A difficulty arises when attempts are made to model the delamination process. If delamination is modelled simply as a crack between two frictionless surfaces the shear stress concentration at the singularity is not significantly reduced by the delamination process but merely moves with the delamination crack tip, i.e. the delamination extends catastrophically through to the ends of the specimen. While such behaviour is sometimes observed in specimens with unidirectional reinforcement, it does not describe the response seen in the present woven-reinforced materials. Here, therefore, an arbitrarily chosen friction coefficient of 0.5 is assumed on the crack surfaces between which slip is allowed to occur. The delamination process is then modelled using the ABAQUS interface element, for which, since there should be no relative movement until slip occurs, a modulus of $1000 \mathrm{GPa}$ is assumed. This also avoids interpenetration between adjoining surfaces.

Analyses were performed for delamination over 2 elements $(0.2 \mathrm{~mm})$ on each side of the failed element (short delamination), 5 elements (1.0mm) on 
each side of the failed element (corresponding to delamination over the length of a unit cell) and 7 elements on each side of the failed element (long delamination, equivalent to half the parallel gauge length of the test specimen). In the light of experimental observations [4], first ply failure was assumed to occur when a critical strain of $1.35 \%$ was fixst reached in the reinforcing plies. This corresponds to the condition for overall tensile fracture of the laminate rather than matrix break-up. Since, however, only tensile stress concentration factors around the failed ply are determined, the results are equally applicable to either situation. In contrast, for any subsequent delamination, which it was assumed took place under constant displacement at the critical strain of $1.35 \%$, specific values of the interlaminar shear stress close to failure are determined. These are likely to be overestimates

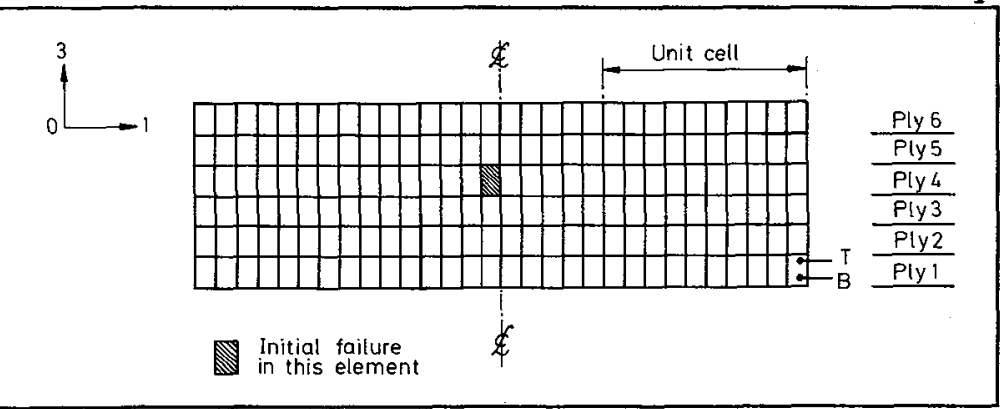

Fig. 2 Finite Element Mesh and Ply Numbering

of those resulting. from matrix breakup.

\section{Results}

Finite element analyses for the tensile stress concentration factor and the shear stress distribution close to the failed ply, without subsequent delamination, are given in Figs. 3a and $b$, respectively, for the interfaces defined in Fig. 2 . A reduction in the longitudinal modulus for the failed element by a factor of $0.1 x$ was assumed. A study has been made of the effect of varying 1) the reduction in longitudinal modulus used to model tensile failure and 2) the extent of the subsequent delamination.

The effect of varying the tensile modulus The shear stresses and tensile stress concentration factors shown in Fig. 3 were determined at the Gauss points at the top of elements in plies 1,2 and 3 and at the bottom of elements in plies 5 and 6 . The resulting tensile and shear stress distributions are, respectively, symmetric and skew-symmetric about the failed element. The tensile stress concentration is highly localised, decaying from a maximum of $2.1 x$ to $\sim 1$.1x within one element in both directions, $i . e$. over about $1 / 10$ of the wavelength of the weave. The only significant values of interlaminar shear stress are on the two interfaces immediately adjacent to the failed ply. On these planes the shear stress decays more slowly, falling to about $10 \%$ of its peak value over a distance of $\sim 7$ elements. Results similar to those shown in Fig.

TABLE II

Effect of Tensile Modulus of Failed Ply on Peak Tensile stress concentration Factor and Peak Interlaminar shear stress for Initial Tensile Failure in PlY 4

$$
E_{1} / 10 \quad E_{1} / 100
$$$$
\mathrm{E}_{1} / 1000
$$

Peak Tensile Stress Concentration Factor Peak Interlaminar Shear stress (MPa)

$\begin{array}{ccc}2.1 x & 2.7 x & 2.8 x \\ 31 & 49 & 52\end{array}$




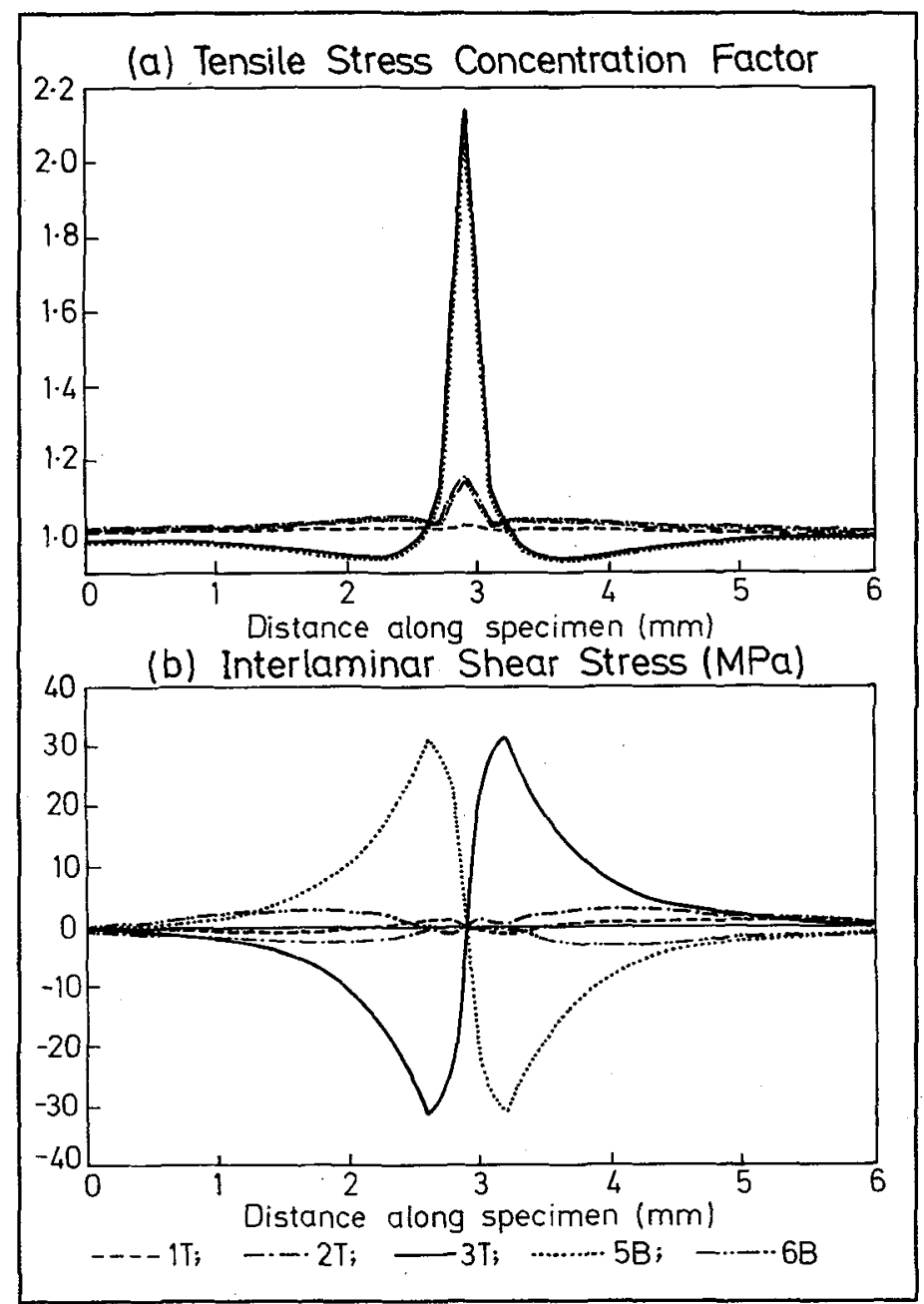

Fig. 3 Tensile and Shear stress Distribution for Failure in Ply 4 (modulus reduction: $\times 0.1$ )
3 were also obtained for assumed reductions in the longitudinal modulus of the failed element by factors of $0.01 x$ and $0.001 x$ and the same general trends were observed. It is clear, see Table II, that although the peak values of both the stress concentration factor and the interlaminar shear stress increase as the tensile modulus is reduced, for reductions greater than $0.01 x$ any further increase is quite small.

The effect of subsequent delamination Assuming the peak interlaminar shear stresses (or the corresponding average interlaminar shear stress distributions) shown in Table II are high enough to cause limited delamination on the planes adjacent to the failed ply, a significant redistribution of the stresses around the failed element is obtained. This is shown in Fig. 4 for the initial stress distribution of Fig. 3 and for delamination over two elements. clearly delamination results in a significant reduction in the peak tensile stress

concentration, from $\sim 2.1 x$, with no delamination to $\sim 1.5 x$ after delamination over 2 elements. The decay in tensile stress concentration outside the delaminated region remains as rapid as before but within this 


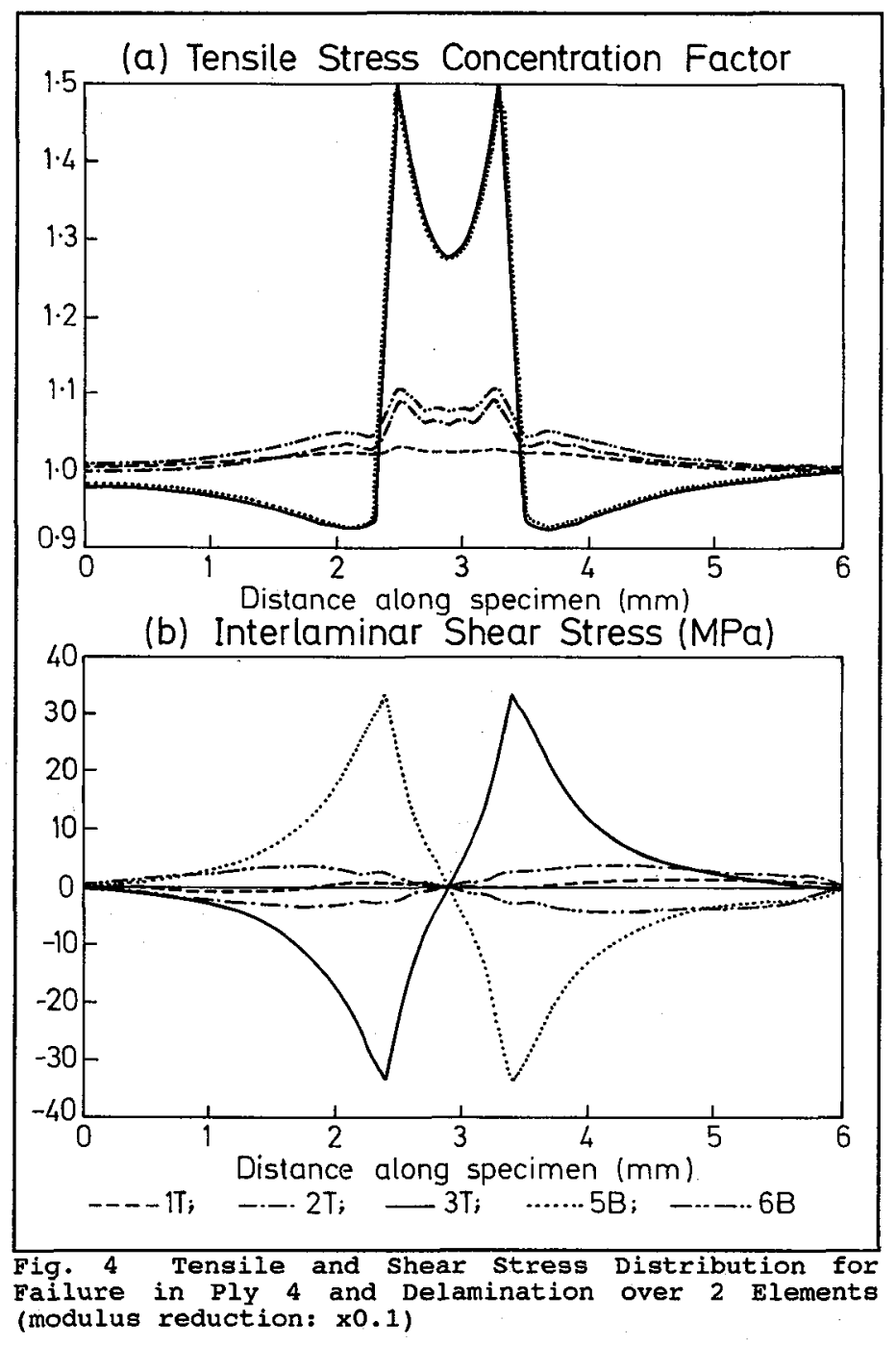

region there is an average tensile stress concentration of the order of $1.3 x$. For delamination over 5 or 7 elements, where the average tensile stress concentration is $1.15 \mathrm{x}$ and $1.1 x$, respectively, this region extends over the whole of one of the unit cells in Fig. 1. The general effect of increasing delamination on the subsequent peak tensile stress concentration factor and its average value of the delaminated region is shown in Table III.

The effect of increasing delamination on the peak value of the shear stress on the interlaminar planes adjacent to the failed ply is shown in Table IV. In each. case the maximum levels of shear stress are obtained after delamination over 2 elements. Further delamination leads to a reduction in the interlaminar shear stresses. However, for tensile moduli in the failed ply of $E_{1} / 100$ and $E_{1} / 1000$, the shear stresses after delamination over 7 elements remain well above those before any delamination had occurred, implying

TABLE III

Effect of Delamination on the Tensile stress Concentration Factor for Initial Tensile Failure in Ply 4

Tensile Modulus in failed ply $\quad \mathbf{E}_{1} / 10 \quad \mathbf{E}_{1} / 100 \quad \mathbf{E}_{1} / 1000$

\begin{tabular}{|c|c|c|c|c|c|c|}
\hline $\begin{array}{l}\text { No delamination } \\
\text { Delamination over }\end{array}$ & $2.1 x$ & & $2.7 x$ & & $2.8 x$ & \\
\hline $\begin{array}{l}2 \text { elements } \\
5 \text { elements }\end{array}$ & $\begin{array}{l}1.5 x \\
1.35 x \\
1.3 x\end{array}$ & $\begin{array}{l}(1.3 x) \\
(1.15 x) \\
(1.1 x)\end{array}$ & $\begin{array}{l}2.0 x \\
1.9 x \\
1.85 x\end{array}$ & $\begin{array}{l}(1.6 x) \\
(1.4 x) \\
(1.3 x)\end{array}$ & $\begin{array}{l}2.1 \mathrm{x} \\
2.05 \mathrm{x} \\
2.05 \mathrm{x}\end{array}$ & $\begin{array}{l}(1.7 x) \\
(1.4 x) \\
(1.35 x)\end{array}$ \\
\hline
\end{tabular}

(Average tensile stress concentration factors over delaminated region are shown in parenthesis) 
TABLE IV

Effect of Delamination on the Peak Interlaminar Shear stress for Initial Tensile Failure in Ply 4

(MPa)

\begin{tabular}{lccc} 
Tensile Modulus in failed ply & $E_{1} / 10$ & $E_{1} / 100$ & $E_{1} / 1000$ \\
\hline No delamination & & 49.1 & 51.7 \\
Delamination over 2 elements & 31.0 & 67.1 & 73.8 \\
Delamination over 5 elements & 22.8 & 58.9 & 68.7 \\
Delamination over 7 elements & 18.8 & 54.9 & 67.8
\end{tabular}

that if the interlaminar shear stresses arising from fibre fracture were to result in delamination, the delamination crack would be likely to propagate catastrophically to the ends of the specimen gauge section. only for the case where the tensile modulus in the failed $\mathrm{ply}$ is $\mathrm{E}_{1} / 10$ does delamination lead to an eventual reduction in the interlaminar shear stresses.

\section{Discussion}

Experimental tensile stress-strain curves for the woven carbon/epoxy specimen modelled in figs. 1 and 2 , under quasi-static and impact loading, are shown in fig. 5 [6]. Specimens were loaded in both the warp and the weft directions and the curves given are for the mean result obtained. The approximate limit of linear elastic behaviour is indicated. At the quasi-static loading rate this occurs at a stress of about $250 \mathrm{MPa}$ and is followed by a significant region of damage accumulation before final failure at a stress of about $420 \mathrm{MPa}$ and a strain of $1.3 \%$. At the dynamic rate the elastic region extends up to a stress of about $500 \mathrm{MPa}$ and the subsequent damage region is much less extensive, final failure occurring at a stress of about $535 \mathrm{MPa}$ and a strain of $1.2 \%$. A small effect of strain rate on the tensile elastic modulus is apparent and is thought to arise from the increasing resistance of the resin matrix to the straightening of the fibre tows at the higher loading rate. This effect has been ignored in the finite element analyses which were all based on the quasi-static elastic constants given in Table $I$. The stress at which a departure from linear elastic behaviour is observed is seen to be strongly rate dependent and is thought to be controlled by a 


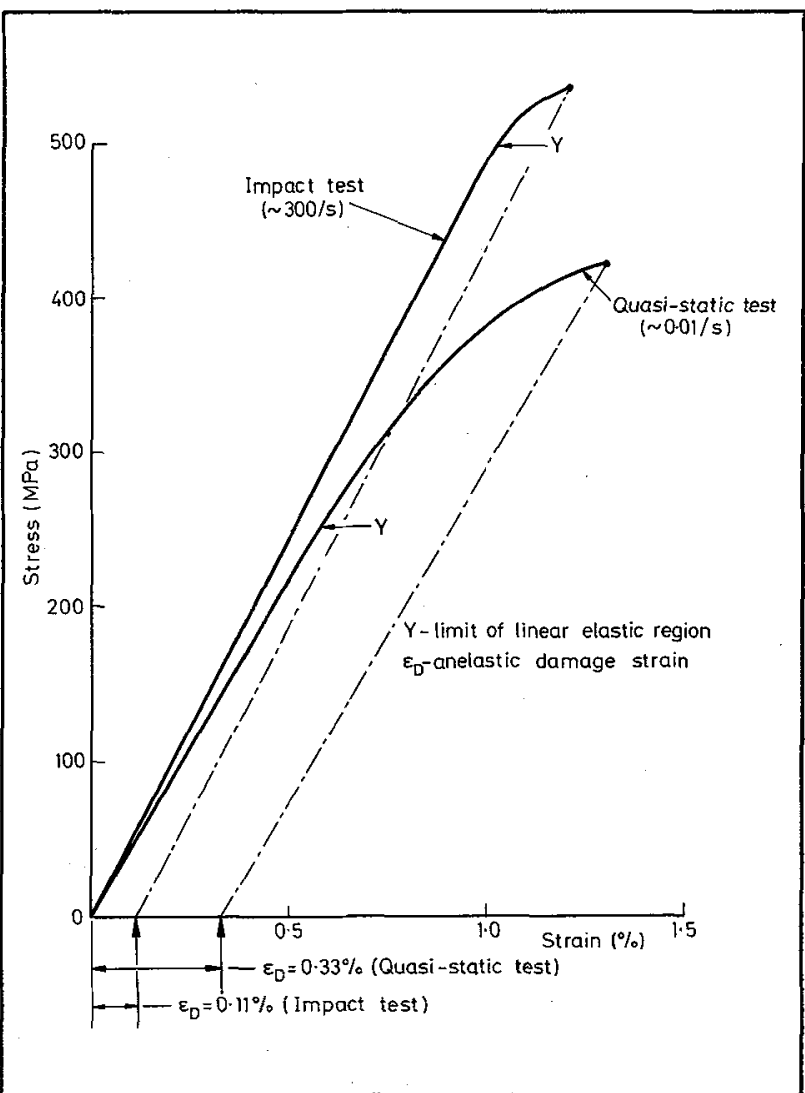

Fig. 5 Mean Experimental Stress-strain Curves for Woven Carbon-Reinforced Laminates

length, see fig. 2 o and that resin break-u ir

loss of integrity in the structure due to the break-up of the resin and its separation from the fibre tows.

For the woven reinforcement geometry shown in Fig. 1 the maximum extension obtainable when all axially-aligned fibre tows are fully straightened over the entire $6 \mathrm{~mm}$ parallel gauge length of the specimen is estimated to be $-0.02 \mathrm{~mm}$, corresponding to an anelastic strain of $0.335 \%$. In practice experimental evidence [3] suggests that the damage zone extends over no more than one half-wavelength of weave on either side of the fracture surface, i.e. over one unit cell in Fig. 1, reducing the maximum anelastic strain due to this effect, when averaged, as in Fig. 5, over the full gauge length, to only $\sim 0.112 \%$. In the event this agrees very well with the actual anelastic strain determined experimentally at fracture under impact loading. It requires that resin break-up occurs in all 6 reinforcing plies at a given cross-section. If we assume that this initiates in ply 4 in the centre of the gauge length, see fig. 2, and that resin break-up also implies delamination over the unit cell in which it occurs, then, for a reduced tensile modulus of $E_{1} / 10$ and delamination over 7 elements, estimates of the average tensile stress concentration factor of $1.1 \times$ (Table III) and the maximum interlaminar shear stress of $18.8 \mathrm{MPa}$ (Table IV) close to the failed ply may be made.

Experimental measurements of the average interlaminar shear stress at failure in this laminate give values of $-26 \mathrm{MPa}$ under quasi-static and $\sim 45 \mathrm{MPa}$ under impact loading [7]. Further local delamination, or fibre pull-out, is unlikely, therefore, in the impact tests so that the failure process merely involves a propagation of resin break up throughout the cross-section, from the initially failed element, followed by tensile fracture of the straightened fibre tows. In contrast, under quasistatic loading the predicted shear stresses are much closer to those which, in practice, give interlaminar failure. Here, therefore, processes controlled by the applied shear stress, i.e. delamination and fibre pull-out, are likely to play a greater part in the failure process, leading to the higher overall failure strains observed experimentally.

\section{Conclusions}

The finite element method has been used to study the stress distribution in a woven carbon reinforced laminate following ply failure, either by break-up of the resin matrix or by fibre fracture, both with and without 
subsequent delamination, and the results discussed in the light of experimental evidence obtained at a quasi-static and an impact rate of strain.

Initial ply failure may be related to break-up of the matrix at an applied stress which increases with increasing strain rate. In impact tests the subsequent anelastic deformation may be accounted for by the straightening of the axially-aligned woven tows. This is followed by fibre fracture leading to immediate catastrophic failure of the laminate. At quasi-static rates of strain fibre straightening alone cannot explain the extent of anelastic deformation. In this case it is suggested that the additional anelastic deformation results from processes controlled by the applied shear stress, e.g. fibre pull-out, prior to catastrophic failure of the laminate. The reduced extent of anelastic deformation under impact loading, therefore, is thought to be due, in part, to the much higher interlaminar shear strength at these rates of strain.

\section{Acknowledgments}

This research was sponsored by the Air Force office of scientific Research, Air Force systems Command, USAF, under Grant No. AFOSR-87-0129.

\section{References}

1. K. Saka and J. Harding, "A simple laminate theory approach to the prediction of the tensile impact strength of woven hybrid composites", Composites, 21, No. 5, September 1990, 439-447.

2. M. G. Bader and A. M. Priest, "Statistical aspects of fibre and bundle strength in hybrid composites", in progress in Science and Engineering of Composites, T Hayashi et al., Eds., Proc. 4th. Int. Conf. on Composite Materials, ICCM IV, Tokyo, $\underline{2}, 1982,1129-1136$.

3. K. Saka and J. Harding, "The deformation and fracture of hybrid reinforced composites under tensile impact", in Proc. IUTAM Symposium on Macro- and Micro-Mechanics of High Velocity Deformation and Fracture, springer-Verlag, Berlin and Heidelberg, 1987, 97-111.

4. J. Harding, K. Saka and M. E. C. Taylor, "The effect of strain rate on the tensile failure of woven-reinforced carbon/glass hybrid composites", in Proc. IMPACT 87, Impact Loading and Dynamic Behaviour of Materials, DGM Informationsgesellschafft mbH, Oberursel, $\underline{2}, 1987,579-586$.

5. Y. L. Li, C. Ruiz and J. Harding, "Failure Analysis of Woven Hybrid composites using a Finite Element Method", Composites Science and Technology, 41, (1991), 129-146.

6. J. Harding, K. Saka and M. E. C. Taylor, "Behaviour of FibreReinforced Composites under Dynamic Tension", (Third Progress Report), Oxford University Engineering Laboratory Report No. OUEL $1654 / 86,1986$.

7. J. Harding, Y. L. Li and M. E. C. Taylor, "The Effect of Strain Rate on the Interlaminar Shear Strength of Woven-Reinforced Laminates", in Proc. ECCM-4, Developments in the Science and Technology of composite materials, eds. J. Fuller et al., Elsevier Applied Science (London and New York, 1990), 517-523. 